\title{
PENINGKATAN KEMAMPUAN BERHITUNG AWAL MELALUI MODIFIKASI BENTUK PERMAINAN CONGKLAK
}

\author{
Vira Muthia Humairo ${ }^{1}$; Zahrina Amelia ${ }^{1}$ \\ ${ }^{1}$ Program Studi Pendidikan Guru Pendidikan Anak Usia Dini, Fakultas Psikologi dan Pendidikan, \\ Universitas Al Azhar Indonesia, Jalan Sisingamangaraja Kebayoran baru, Jakarta Selatan 12110 \\ Penulis untuk Korespondensi/ E-mail: zahrina.amelia@ uai.ac.id
}

\begin{abstract}
Abstrak - Perkembangan kognitif merupakan aspek yang penting dalam mengembangkan kemampuan berpikir anak, salah satunya yaitu mengenal konsep lambang bilangan. Penelitian ini bertujuan untuk mengetahui bagaimana peningkatan kemampuan mengenal konsep lambang bilangan 1 - 10 melalui permainan modifikasi congklak pada anak usia 5 - 6 tahun di RA/TK Islam Amali. Penelitian ini merupakan penelitian tindakan kelas (PTK) yang menggunakan model Kemmis dan Mc Taggart yang dilakukan selama 2 siklus, di mana satu siklus terdiri dari 2 kali pertemuan. Subjek penelitian ini adalah 15 anak, yang terdiri dari 9 anak laki-laki dan 5 anak perempuan. Teknik pengumpulan data yang digunakan dalam penelitian ini adalah observasi kemampuan anak dalam mengenal konsep lambang bilangan 1 - 10, aktivitas guru dan anak serta dokumentasi. Teknik analisis data yang digunakan pada penelitian ini adalah deskriptif kualitatif dengan menggunakan perhitungan statistika sederhana.Berdasarkan hasil penelitian diketahui bahwa terdapat peningkatan dalam kemampuan mengenal konsep lambang bilangan $1-10$ melalui permainan pohon hitung. Hal ini diketahui dari rata-rata anak yang mendapat skor 3 pada setiap indikator yaitu indikator membilang 1 - 10 siklus I sebesar $69.1 \%$ dan siklus II sebesar $100 \%$ artinya terdapat peningkatan sebesar $30.9 \%$. Pada indikator menghubungkan benda-benda konkret dengan lambang bilangan 1 - 10 siklus I sebesar $55.4 \%$ dan siklus II sebesar $77,6 \%$ artinya terdapat peningkatan sebesar $22.2 \%$ dan pada indikator mengurutkan lambang bilangan 1 - 10 siklus I $44.7 \%$ dan siklus II sebesar $77.6 \%$ artinya terdapat peningkatan sebesar $32.9 \%$. Pencapaian di siklus II sudah melebihi indikator keberhasilan yang telah ditentukan yaitu sebesar $75 \%$.
\end{abstract}

Kata Kunci: Konsep Lambang Bilangan, Permainan Modifikasi Congklak

Abstract - Cognitive development is an important aspect in developing children's thinking abilities, one of which is to recognize the concept of the number symbol. This study aims to find out how to increase the ability to recognize the concept of the symbol number 1-10 through a game of congklak modification in children in RA/TK Islam Amali.This research is a classroom action research (CAR) that uses the Kemmis and Mc Taggart Models Conducted for 2 meetings. The subjects of this study were 15 children, consisting of 9 boys and 5 girls. Dara Collection techniques used in this study were observation of children's ability to recognize the concept of the symbol number 1-10, the activities of teachers and children as well as documentation. The data analysis technique used in this study was descriptive qualitative using simple statistical calculations.Based on the results of the study note that there is an increase in the ability to recognize the concept of the symbol number 1-10 through the modification of the game congklak. This is known from the average child who gets a score of on each indicator namely the indicator counting 1-10 cycles I amounted to $69.1 \%$ and cycles II amounted to $100 \%$ meaning there was an increase of the 30.9\%. in indicators connecting concreate objects with symbol numbers 1-10 cycles II amounted to $77.6 \%$ meaning there was an increase of $32.9 \%$. Achievement in the second cycles has exceeded the predetermined success indicators which is equal to $75 \%$.

Keywords: Concept of Number Symbols, Congklak Modification Game 


\section{PENDAHULUAN}

$\mathrm{P}$ endidikan

Taman

Kanak-Kanak merupakan salah satu bentuk pendidikan anak usia dini yang memiliki peranan sangat penting untuk mengembangkan kepribadian anak serta mempersiapkan mereka memasuki jenjang pendidikan selanjutnya, Pendidikan adalah pembelajaran, pengetahuan, keterampilan, dan kebiasaan sekelompok orang yang diturunkan dari satu generasi ke generasi berikutnya melalui pengajaran, pelatihan, atau penelitian. Dalam Kamus Besar Bahasa Indonesia (KBBI) Pendidikan berasal dari kata dasar didik, yaitu: usaha untuk membuat anak menjadi lebih pintar melalui upaya pengajaran dan membuat praktek. Pendidikan sendiri mempunyai pengertian: proses pengubahan sikap dan tata laku seseorang atau kelompok orang dalam usaha mendewasakan manusia melalui upaya pengajaran dan latihan, proses perbuatan, cara mendidik. Ki Hajar Dewantara mengartikan pendidikan sebagai daya upaya untuk memajukan budi pekerti, pikiran serta jasmani anak, agar dapat memajukan kesempurnaan pada diri sendiri yaitu kesempurnaan dan menghidupkan anak-anak yang selaras dengan alam dan masyarakat.

Anak merupakan pribadi yang unik, senantiasa memiliki berbagai karakteristik yang berbedabeda antara anak satu dengan anak lainnya. Pada masa golden age terutama, anak sedang mengalami pertumbuhan dan perkembangan yang sangat pesat terhadap segala aspek perkembangannya. Untuk mengoptimalkan hal tersebut, diperlukan stimulus untuk pengembangan semua potensi yang terlibat di dalam kehidupan anak.

Salah satu potensi yang sangat penting untuk distimulasi adalah kemampuan berhitung awal (permulaan), sebagaimana yang dimaksudkan Smith (2009) bahwa: "Counting is universal skill that appears to be asily acquired at an early age". Pengertian tersebut dapat diartikan bahwa pada anak usia dini, anak memiliki berbagai potensi, oleh karena itu potensi yang dimiliki oleh anak usia dini harus dikembangkan secara optimal agar anak memiliki keberhasilan di masa yang akan datang terutama kemampuan berhitung. Sedangkan Dodge (2002) mengemukakan bahwa berhitung adalah: "Counting is one of the earliest number concept to emerge".
Berhitung merupakan salah satu dari konsep angka yang paling mudah untuk dimunculkan. Dari pengertian ini dapat diartikan bahwa berhitung merupakan pengenalan konsep angka yang paling mudah untuk dipelajari anak usia dini, dan berhitung juga merupakan awal dari pembelajaran dari matematika anak usia dini. Guru hendaknya memberikan konsep-konsep dasar pembelajaran semaksimal mungkin karena pada usia dini anak mudah menerima berbagai rangsangan yang diberikan lingkungan dan orang dewasa yang berada di sekitarnya. Menurut Charleswoth (2005) berhitung merupakan: "Counting is learned for the most part through naturalistic and informal activities suppoted by structured lessons".

Salah satu aspek yang harus dikembangkan oleh guru TK sebagai pendidik di sekolah pada anak usia dini adalah aspek perkembangan kognitif. Perkembangan kognitif merupakan aspek perkembangan yang penting dalam mengembangkan kemampuan berpikir anak. Lingkup perkembangan kognitif untuk anak usia 5-6 tahun terbagi menjadi tiga yaitu Menyebutkan lambang bilangan 1-10, menggunakan lambang bilangan untuk menghitung serta mencocokan bilangan dengan lambang bilangan.

Kemampuan berpikir simbolik untuk anak usia 5-6 tahun menurut Permendikbud RI Nomor 137 Tahun 2014 tentang Standar Nasional Pendidikan Anak Usia Dini, yaitu anak mampu menyebutkan lambang bilangan 1-10, menggunakan lambang bilangan untuk menghitung serta mencocokan bilangan dengan lambang bilangan.

Menggunakan lambang bilangan untuk berhitung sangatlah penting dalam kehidupan sehari-hari anak, anak terlibat langsung dalam penggunaan lambang bilangan sebagai contoh ketika anak membilang benda saat anak merapikan mainannya, membaca lambang bilangan atau angka pada jam sehingga anak mengetahui waktunya, ditanya tentang usia dan anak mampu menyebutkan angkanya, menghitung jarak yang ditempuh misalnya dari rumah ke sekolah, bermain jual beli sehingga anak mampu membaca angka/nominal yang tertera pada uang, mengetahui nomor rumah dan lain-lain. 
Melihat pentingnya mengenal konsep lambang bilangan bagi anak, maka guru memiliki peran penting dalam memberikan stimulasi yang sesuai dengan kebutuhan dan perkembangan anak. Untuk itu, dalam mengenalkan konsep lambang bilangan harus dilakukan dengan cara bertahap. Tahap pertama adalah tahap konsep, yaitu tahap utama sebelum anak mengenal lambang. Pada tahap ini, biasanya anak akan melakukan kegiatan bermain seperti menghitung benda yang dilihatnya atau berada di sekitarnya.

Tahap kedua adalah tahap transmisi/ tingkat menghubungkan konsep konkret dengan lambang bilangan yaitu anak sudah benar-benar memahami tahap konsep. Pada tahap ini anak mulai diajarkan tentang lambang bilangan dan anak sudah mengetahui kesesuaian jumlah benda dengan lambang bilangan yang mewakilinya. Tahap ketiga adalah tahap lambang, yaitu tahap terakhir setelah anak sudah melewati tahap-tahap sebelumnya. Berdasarkan ketiga tahap tersebut, maka indikator kemampuan mengenal konsep lambang bilangan yang ditentukan dalam penelitian ini adalah menyebutkan lambang bilangan 1-10, menggunakan lambang bilangan untuk menghitung serta mencocokan bilangan dengan lambang bilangan.

Untuk mengembangkan kegiatan berhitung dibutuhkan suatu metode yang tepat dan melihat berbagai aspek yang dapat mendukung anak. Salah satu metode yang dapat dilakukan yaitu kembali pada prinsip pembelajaran anak usia dini melalui sarana bermain. Belajar melalui bermain dapat mengasah dan meningkatkan kecerdasan yang dimiliki anak.

Pengalaman anak lewat aktivitas bermain dapat memberikan dasar yang kuat bagi pencapaian macam-macam keterampilan yang sangat diperlukan bagi pemecahan masalah dalam kehidupan dikemudian hari. Anak yang banyak menggunakan waktu untuk bermain cenderung lebih dapat menyelesaikan masalah dikehidupan selanjutnya.

Metode bermain penting untuk diterapkan di taman kanak-kanak karena melalui bermain anak akan belajar berinteraksi dengan temannya, belajar bekerjasama, berbagi, dan bersikap toleransi. Hal ini didukung dengan hasil penelitian terdahulu oleh Astuti (2012) yang menyatakan bahwa metode bermain dianggap penting karena dengan bermain anak akan belajar berkomunikasi, dan berinteraksi dengan orang lain.

Salah satu permainan yang dapat dilakukan oleh anak di sekolah ialah permainan tradisional congklak. Permainan congklak merupakan permainan yang dimainkan oleh dua orang anak, memakai sebuah papan congklak, yang memiliki 16 lubang, mempunyai biji congklak yang biasanya dari batu kecil, cangkang kerang, biji tumbuhan ataupun biji kelereng. Lubang yang berada dalam papan congklak berdiameter sama, namun 2 lubang paling ujung berukuran lebih besar sebagai indung atau rumah bagi pemain untuk mengumpulkan bji congklak.

Pentingnya kemampuan berhitung bagi anak serta upaya pelestarian permainan tradisional melalui kegiatan dalam pembelajaran, maka perlu dilakukan penelitian untuk meningkatkan kemampuan berhitung anak melalui permainan Congklak.

\section{METODE PENELITIAN}

Sesuai dengan tujuan penelitian ini yaitu untuk meningkatkan kemampuan mengenal konsep lambang bilangan $1-10$ melalui permainan modifikasi congklak pada anak usia 5-6 tahun di RA/TK Islam Amali, maka jenis penelitian yang akan digunakan adalah Penelitian Tindakan Kelas (PTK). Penelitian Tindakan Kelas dilaksanakan di RA/TK Islam Amali yang terletak di Komp. Puri Kartika 1 Tajur, RT.003/RW.006, Ciledug, Kota Tangerang, Banten. Subjek dalam penelitian ini adalah anak Kelompok B1 yang berusia 5-6 tahun di RA/TK Islam Amali tahun ajaran 2019-2020 berjumlah 15 anak yang terdiri dari 11 anak laki-laki dan 4 anak perempuan.

Dalam perencanaannya, Kemmis (dalam Sukidin, dkk, 2010: 48-49) menggunakan sistem spiral refleksi diri yang dimulai dengan rencana, tindakan, pengamatan, refleksi dan perencanaan kembali yang merupakan dasar untuk suatu ancang-ancang pemecahan permasalahan. Langkah-langkah dalam penelitian ini diuraikan sebagai berikut:

1. Tahapan Perencanaan (Planning)

a. Pembuatan desain pembelajaran yang memuat Rencana Pelaksanaan Pembelajaran 
Harian (RPPH), lembar observasi guru dan anak serta cara penilaian dalam pembelajaran yang telah disetujui oleh guru kelas.

b. Persiapan sarana dan prasarana penelitian meliputi:

1) Pembuatan media permainan modifikasi congklak yang akan digunakan dalam pembelajaran mengenal konsep lambang bilangan.

a) Adapun bahan-bahan yang diperlukan dalam pembuatan permainan modifikasi congklak yaitu kayu, lem dan cat.

b) Permainan modifikasi congklak akan dilakukan pada kegiatan inti dalam waktu \pm 90 menit. Adapun penjelasan waktu tersebut sebagai berikut:

(1) Guru memberikan contoh dan menjelaskan cara permainan modifikasi congklak serta aturan mainnya ( \pm 10 menit)

(2) Anak melakukan kegiatan permainan modifikasi congklak ( \pm 70 menit)

(3) Guru melakukan evaluasi/ recalling ( \pm 10 menit)

c) Adapun cara permainan modifikasi congklak ini adalah sebaai berikut:

(1) Guru membagi anak menjadi dua barisan. Kemudian, anak yang belum dipanggil namanya diminta untuk mengerjakan kegiatan lain. Setelah itu, anak diminta untuk melakukan kegiatan membilang pada permainan modifikasi congklak

(2) Di dalam permainan modifikasi congklak ada 3 lubang yang terdiri dari 2 lubang untuk membilang dan 1 lubang untuk menaruh hasil dari membilang tersebut dan masing-masing lubang diberi warna merah dan kuning.

2) Stiker bintang untuk memotivasi anak dalam pembelajaran.

a) Melakukan diskusi dan memberikan arahan agar praktisi dalam melaksanakan perannya sesuai dengan rencana.

b) Menyusun instrumen pengumpulan data berupa pedoman observasi yaitu lembar observasi aktivitas anak dan guru serta lembar observasi kemampuan anak dalam mengenal konsep lambang bilangan $1-10$.

\section{Tahapan Pelaksanaan Tindakan}

Dalam tahap pelaksanaan tindakan adalah memberikan tindakan sesuai dengan tahap perencanaan yang telah disusun.

1. Tahapan Pengamatan (observing).

Observasi ini dilakukan dalam setiap pelaksanaan siklus, dimana kegiatan dilakukan peneliti dalam tahap observasi ini adalah:

a. Memperhatikan anak selama pembelajaran berlangsung dan memberikan bantuan pada anak yang mengalami kesulitan dalam pembelajaran.

b. Memperhatikan dan mengamati anak dengan mencatat kejadian yang terjadi dalam pembelajaran tersebut serta mencatat kemampuan anak dalam mengenal konsep lambang bilangan 1 10.

c. Mengamati aktivitas guru selama memberikan kegiatan pembelajaran.

d. Pengamatan yang dilakukan pada siklus I sangat berpengaruh pada perencanaan pembelajaran yang akan dilakukan pada siklus selanjutnya. Untuk itu hasil pengamatan pada siklus I akan segera didiskusikan bersama guru untuk mencari alternatif-alternatif pemecahan untuk melakukan perbaikan pada siklus II, hal ini dilakukan agar kekurangan tersebut tidak lagi terulang pada siklus berikutnya.

2. Tahapan refleksi.

Tahap refleksi pada siklus I akan dijadikan acuan perencanaan tindakan pada siklus II. Melalui data ini, dapat dilakukan refleksi diri untuk mengetahui berbagai hal yang mungkin memerlukan perbaikan dalam pembelajaran pada siklus I.

Teknik pengumpulan data yang digunakan adalah observasi dan dokumentasi. Observasi dilaksanakan selama proses pembelajaran sedang berlangsung yang dibantu oleh kolabolator. Dalam penelitian ini, peneliti menggunakan pedoman observasi sebagai instrumen pengamatan. Pedoman observasi yang digunakan sebagai instrumen penelitian 
ini adalah lembar observasi tentang indikator pembelajaran peningkatan kemampuan mengenal konsep lambang bilangan 1-10 pada anak usia $4-5$ tahun berdasarkan tahap kemampuan mengenal konsep lambang bilangan pada anak kelompok B2 Melati (usia 5-6 tahun) yaitu membilang/ menyebutkan, menghubungkan benda-benda konkret dengan lambang bilangan dan mengurutkan lambang bilangan 1 - 10 pada saat proses pembelajaran dengan memberi check list. Selain itu, dalam penelitian ini peneliti juga menggunakan lembar observasi guru dan anak untuk mengamati aktivitas guru dan anak selama proses KBM. Sedangkan dokumentasi digunakan sebagai penguat data. Dokumentasi dalam penelitian ini adalah berupa foto yang diambil berdasarkan proses pembelajaran anak.

Data yang telah terkumpul akan dianalisis menggunakan teknik analisis deskriptif kualitatif untuk menggambarkan kondisi atau suasana pembelajaran baik dari guru maupun anak dan perhitungan statistik sederhana untuk mengukur skor/presentase keberhasilan kemampuan anak dalam mengenal konsep lambang bilangan $1-10$. Dengan demikian dapat diketahui sejauh mana peningkatan kemampuan anak dalam mengenal konsep lambang bilangan yang telah dicapai setelah distimulasi menggunakan permainan modifikasi congklak.

Kriteria ketuntasan dan keberhasilan pada penelitian ini apabila $75 \%$ anak sudah mampu untuk membilang, menghubungkan dan mengurutkan lambang bilangan $1-10$ atau dapat dikatakan bahwa masing-masing indikator anak mendapatkan skor 3. Data yang dianalisa dalam persentase menggunakan rumus:

$$
\mathrm{P}=\frac{\mathrm{F}}{\mathrm{N}} \times 100 \%
$$

Keterangan:

$\mathrm{P}=$ Angka Presentasi

$\mathrm{F}=$ Frekuensi aktivitas/skor anak

$\mathrm{N}=$ Jumlah anak dalam satu kelas

\section{HASII DAN PEMBAHASAN}

Penelitian Tindakan Kelas (PTK) ini dilaksanakan menjadi dua siklus, di mana masing-masing siklus terdiri dari dua kali pertemuan. Indikator yang akan dinilai pada penelitian ini adalah kemampuan anak dalam membilang $1-10$, menghubungkan bendabenda konkret dengan lambang bilangan $1-10$ dan mengurutkan lambang bilangan $1-10$ melalui modifikasi bentuk permainan congklak.

1. Siklus I

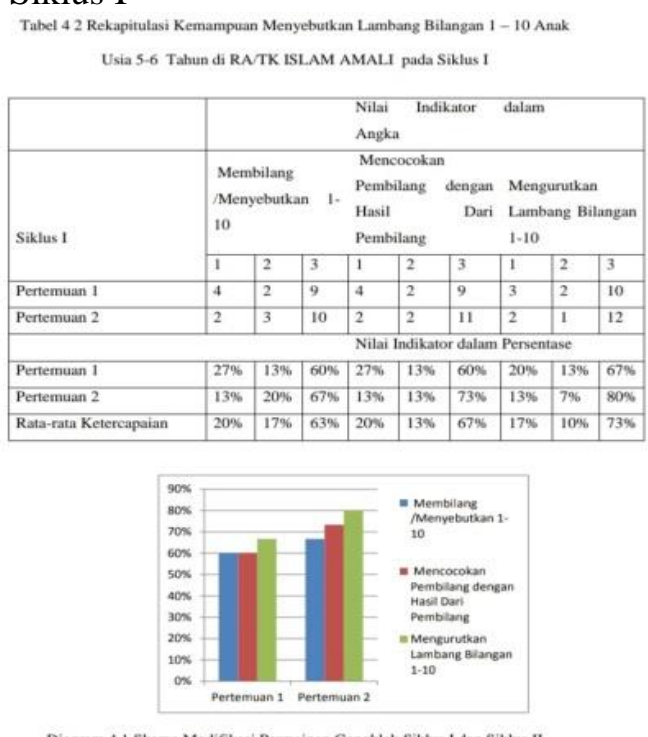

Gambar 1. Hasil kegiatan siklus 1

Berdasarkan data di atas, dapat diketahui bahwa kemampuan menyebutkan lambang bilangan 110 pada anak usia 5-6 tahun (Kelompok B1 Melati) di RA/TK Islam Amali pada masingmasing disiklus I adalah sebagai berikut:

a. Kemampuan menyebutkan lambang bilangan 1-10 pada pertemuan pertama, pada indikator membilang/ menyebutkan 110 , yang mendapatkan skor 1 sebanyak 4 anak (27\%), skor 2 sebanyak 2 anak (13\%) dan skor 3 sebanyak 9 anak (60\%). Pada Indikator mencocokan pembilang dengan hasil dari membilang, anak yang mendapatkan skor 1 sebanyak 4 anak (27\%), skor 2 sebanyak 2 anak (13\%), dan skor 3 sebanyak 9 anak (60\%). Sedangkan Pada Indikator Mengurutkan lambang bilangan 1-10, anak yang mendapatkan skor 1 sebanyak 3 anak (20\%), skor 2 sebanyak 2 anak (13\%), dan skor 3 sebanyak 10 anak $(67 \%)$.

b. Kemampuan menyebutkan lambang bilangan 1-10 pada pertemuan kedua, pada indikator membilang/menyebutkan 1-10, yang mendapatkan skor 1 sebanyak 2 anak (13\%), skor 2 sebanyak 3 anak (20\%), skor 3 sebanyak 10 anak (67\%). Pada indikator mencocokan pembilang dengan hasil dari 
pembilang, anak yang mendapatkan skor 1 sebanyak 2 anak (13\%), skor 2 sebanyak 2 anak (13\%), skor 3 sebanyak 11 anak (73\%). Sedangkan pada indikator mengurutkan lambang bilangan 1-10, anak yang mendapatkan skor 1 sebanyak 2 anak (13\%), skor 2 sebanyak 1 anak (7\%), skor 3 sebanyak 12 anak (80\%).

Data di atas menunjukkan bahwa terdapat peningkatan kemampuan menyebutkan lambang bilangan 1-10 dari setiap pertemuan pada siklus I. Pada indikator membilang/menyebutkan angka rata-rata ketercapaian anak mendapatkan skor 3 yaitu 63\%. Pada indikator mencocokan pembilang dengan hasil dari pembilang angka rata-rata ketercapaian anak mendapatkan skor 3 yaitu $67 \%$ dan indikator mengurutkan lambang bilangan 1-10 angka rata-rata ketercapaian anak mendapatkan skor 3 yaitu $73 \%$.

Meskipun terdapat peningkatan pada Siklus I pada tiap-tiap indikator penilaiannya, namun hal tersebut belum mencapai indikator keberhasilan yang telah ditetapkan oleh peneliti yaitu sebesar $75 \%$, sehingga peneliti merasa perlu adanya upaya tindakan lanjut ke siklus II untuk meningkatkan kemampuan anak dalam mengenal konsep lambang bilangan 1-10.

Hasil pengamatan aktivitas guru dan anak pada saat proses pembelajaran di siklus I diuraikan melalui table berikut ini:
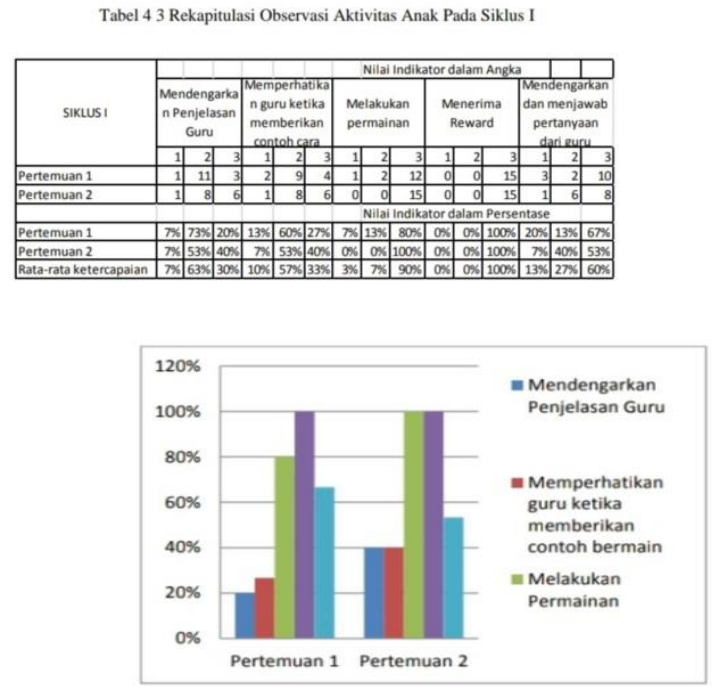

Diagram 42 Diagram Observasi Aktivitas Anak Pada Siklus I

Gambar 2. Hasil observasi aktivitas anak
Berdasarkan data di atas, dapat diketahui bahwa presentase rata-rata aktivitas anak apada setiap pertemuan di siklus I adalah sebagai berikut:

a. Aktivitas mendengarkan penjelasan guru ketika menjelaskan tujuan permainan, ratarata anak yang mendapatkan skor 3 yaitu sebesar 30\%, rata-rata anak yang mendapatkan skor 2 yaitu sebesar $63 \%$ dan rata-rata anak yang mendapatkan skor 1 yaitu sebesar $7 \%$.

b. Aktivitas memperhatikan guru ketika memberikan contoh car permainan modifikasi congklak rata-rata anak yang mendapatkan skor 3 yaitu sebesar 33\%, rata-rata anak yang mendapatkan skor 2 yaitu sebesar $57 \%$, rata-rata anak yang mendapatkan skor 1 yaitu sebesar $7 \%$.

c. Aktivitas melakukan permainan modifikasi congklak rata-rata anak yang mendapatkan skor 3 yaitu sebesar $90 \%$, rata-rata yang mendapatkan skor 2 yaitu sebesar $7 \%$, ratarata yang mendapatkan skor 1 yaitu sebesar $3 \%$.

d. Aktivitas menerima reward, rata-rata anak yang mendapatkan skor 3 yaitu sebesar $100 \%$, rata-rata anak yang mendapatkan skor 2 yaitu sebesar $0 \%$, rata-rata yang mendapatkan skor 1 yaitu sebesar $0 \%$.

e. Aktivitas mendengar dan menjawab pertanyaan guru ketika evaluasi yang mendapatkan skor 3 yaitu sebesar $60 \%$, rata-rata yang mendapatkan skor 2 yaitu $27 \%$, rata-rata yang mendapatkan skor 1 yaitu sebesar $13 \%$.

f. Berdasarkan lima aktivitas penilaian observasi anak dapat dikatakan bahwa kelima aktivitas tersebut belum dapat dilaksanakan anak sesuai sebagaimana mestinya, sehingga masih perlu adanya bimbingan atau arahan agar anak dapat lebih tertib dan mau memperhatikan apa yang sedang guru jelaskan serta contohkan ketika kegiatan pembelajaran sedang berlangsung maupun ketika evaluasi/recalling. Selain itu, dalam melakukan $7 \%$ anak yang mendapatkan skor 2 yaitu melakukan permainan modifikasi congklak kurang sesuai dengan cara yang telah dicontohkan guru (anak baru dapat melakukan dua langkah permainan) dan masih memerlukan bimbingan serta bantuan dalam melakukannya. Selanjutnya, pada aktivitas mendengarkan dan menjawab pertanyaan guru masih terdapat $27 \%$ anak yang 
mendapatkan skor 2 yaitu anak belum terlalu fokus untuk mendengarkan dan menjawab pertanyaan guru. Tabel 44 Rekapitulasi Observasi Aktivitas Guru Siklus I

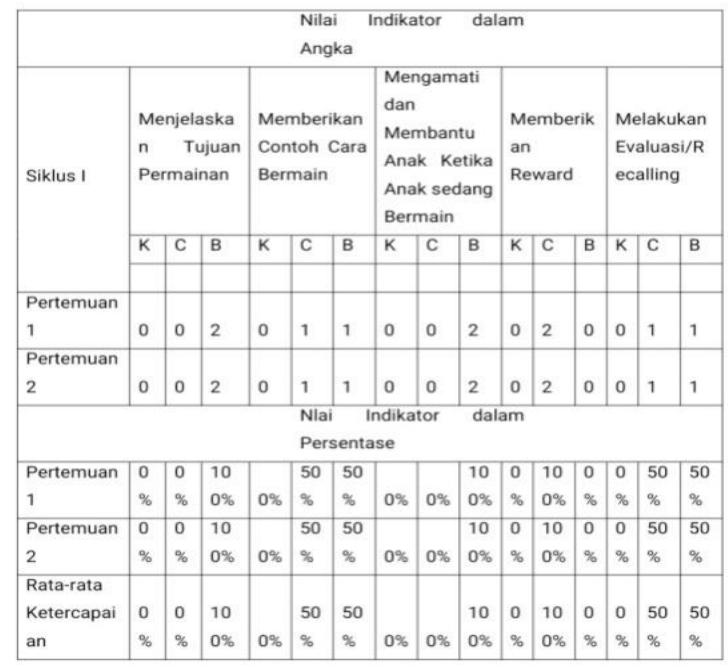

Gambar 3. Hasil observasi aktivitas guru

Berdasarkan data di atas, dapat diketahui bahwa aktivitas guru pada menjelaskan tujuan permainan dan mengamati serta membantu anak ketika sedang melakukan permainan modifikasi congklak sudah mendapatkan skor/ nilai b (baik) atau sudah melakukan sebagaimana mestinya. Namun, pada aktivitas memberikan contoh cara permainan modifikasi congklak aktivitas guru masih dinilai kurang sebagaimana mestinya karena terlalu cepat dalam mencontohkan cara permainan modifikasi congklak, dan setelah mencontohkan, guru hanya memamnggil salah satu anak untuk mencontohkannya kembali padahal masih terdapat anak yang belum memahami apa yang harus dilakukan. Sedangkan pada aktivitas memberikan reward kepada anak pada pertemuan pertama guru dinilai kurang dalam menjelaskan tujuan dari reward tersebut dan pada pertemuan kedua dan ketiga guru tidak memberikan reward kepada anak. Selain itu, pada aktivitas evaluasi suara guru masih dinilai kurang lantang.

Berdasarkan hasil observasi maka dilakukan refleksi, yang dipaparkan sebagai berikut.

a. Observasi Aktivitas Guru

Berdasarkan observasi dapat diketahui bahwa aktivitas guru dalam mengamati dan membantu anak ketika sedang melakukan permainan modifikasi congklak dinilai sudah sesuai sebagaimana semestinya atau dapat dikatakan guru sudah mendapatkan skor b (baik). Namun pada tiga aktivitas lainnya guru masih dinilai kurang atau belum sesuai sebagaimana semestinya.

Adapun hambatan pada ketiga aktivitas lainnya adalah sebagai berikut:

1) Memberikan contoh cara permainan modifikasi congklak. Guru terlalu cepat dalam mencontohkan permainan modifikasi congklak.

2) Memberikan reward kepada anak. Guru kurang menjelaskan tujuan dari diberikannya reward kepada anak. Rewrd yang diberikan guru sebaiknya dalam berbagai variasi

3) Melakukan evaluasi. Ketika guru melakukan evaluasi suara guru kurang lantang sehingga tidak seluruh anak dapat mendengarnya dan menyebabkan beberapa anak sesekali mengobrol dengan temannya.

b. Observasi Aktivitas Anak

1) Mendengarkan penjelasan guru. Sebagian besar anak mendengarkan walaupun sesekali mengobrol dan mengajak teman untuk bercanda. Namun, terdapat pula anak yang tidak mendengarkan.

2) Memperhatikan guru ketika memberikan contoh permainan. Pada pertemuan pertama beberapa anak masih kurang memahami apa yang harus dilakukan dalam permainan modifikasi congklak sehingga masih harus dibimbing dan dibantu oleh guru.

3) Melakukan permainan modifikasi congklak. Permainan modifikasi congklak dilakukan di dalam kelas bersamaan dengan anak yang sedang melakukan kegiatan lain, sehingga menyebabkan pembelajaran kurang kondusif karena terdapat sebagian anak yang masih mengobrol, bercanda, jalanjalan, memberi tahu teman yang sedang bermain modifikasi congklak dan anak yang sedang bermain modifikasi congklak kurang leluasa. Beberapa anak terlihat masih ragu-ragu dan takut salah saat membilang, menghubungkan lambang bilangan 1-10 padahal beberapa anak sudah mengetahui atau sudah mengerti. Beberapa anak kesulitan mencari kartu angka karena kartu angka yang di sediakan terlalu banyak. 
4) Anak menerima reward. Anak tidak mengerti tujuan diberikannya reward oleh guru.

5) Evaluasi. Anak mendengarkan dan menjawab pertanyaan guru sebagian besar anak mau mendengarkan dan menjawab pertanyaan guru walaupun sesekali mengobrol dan mengajak teman untuk bercanda. Selain itu, terdapat pula hambatan lainnya, yaitu anak yang tidak masuk karena sakit, izin dan tanpa keterangan serta perlunya menjalin kerjasama kembali antara peneliti dan guru mengenai peran dalam penelitian.

\section{Siklus II}

Hasil dari pelaksanaan tindakan siklus I dalam mengenal konsep lambang bilangan 1-10 pada anak usia 5-6 tahun sudah mengalami peningkatan, walaupun belum mencapai indikator keberhasilan yang telah ditetapkan oleh peneliti karena dalam pelaksanaan tindakan pada siklus I masih terdapat kekurangan pada aktivitas pelaksanaan permainan modifikasi congklak, sehingga diperlukannya suatu perbaikan yang diharapkan pada siklus II tidak terulang lagi. Untuk itu, peneliti dan kolabolator merencanakan beberapa langkah perbaikan dalam pelaksanaan permainan modifikasi congklak yang akan di lakukan pada siklus II.

Berdasarkan observasi dan refleksi dapat diketahui aktivitas guru dalam mengamati dan membantu anak ketika sedang melakukan permainan modifikasi congklak dinilai sudah sesuai sebagaimana mestinya atau dapat dikatakan guru sudah mendapat skor b (baik). Namun, pada tiga aktivitas lainnya guru masih dinilai kurang atau belum sesuai sebagaimana mestinya. Adapun rencana perbaikan pada siklus I, adalah sebagai berikut:

a. Menjelaskan tujuan permainan modifikasi congklak

b. Guru disarankan untuk melantangkan suara, agar seluruh anak dapat mendengarkannya.

c. Memberikan contoh cara permainan modifikasi congklak. Guru menjelaskan dan mencontohkan permainan dengan perlahanlahan atau secara detail agar anak lebih memahami cara permainannya dan tidak ragu-ragu lagi. Pada saat guru mencontohkan permainan modifikasi congklak guru sebaiknya melibatkan seluruh anak untuk mencoba secara langsung dengan memanggil anak bergantian.

d. Pelaksanaan permainan modifikasi congklak. Permainan modifikasi congklak akan tetap dilakukan dalam bentuk kompetisi (dilakukan oleh dua orang anak secara bersamaan). Namun, saat kegiatan berlangsung anak yang lain tidak mengganggu teman yang sedang bermain permainan modifikasi congklak, karena akan membuat anak yang sedang bermain menjadi kurang berkonsentrasi. Selain itu, pada proses kegiatan guru membagi anak berdasarkan tingkat kemampuan yang hampir sama, contoh: pada saat pelaksanaan permainan modifikasi congklak anak yang sekiranya belum mampu dipasangkan dengan anak yang belum mampu. Melaksanakan langkahlangkah permainan modifikasi congklak sesuai dengan perencanaan siklus II. Pada kegiatan mengurutkan lambang bilangan 110, guru mengurangi jumlah kartu angka agar anak tidak kesulitan dalam mencarinya saat melakukan permainan tersebut.

e. Memberikan reward kepada anak. Guru menjelaskan tujuan diberikannya reward kepada anak. Selain itu, sebaiknya reward yang diberikan guru lebih bervariasi sesuai dengan apa yang disukai oleh anak-anak, misalnya wafer tango atau permen yupi dengan berbagai macam bentuk, serta pada hari terakhir pembelajaran guru memberikan snack dan alat tulis kepada anak untuk meningkatkan minat anakdatang ke sekolah dan semangat dalam melakukan kegiatan permainan modifikasi congklak.

f. Melakukan evaluasi. Guru disarankan untuk mengkondisikan kembali kelas agar lebih tertib dan melantangkan suara. Selain merubah teknik pelaksanaan tindakan sesuai masing-masing aktivitas, peneliti dan juga menjalin kerjasama kembali terkait dengan peran penelitian dan berdiskusi tentang tema pembelajaran. Kemudia, peneliti membuat RPPH yang telah didiskusikan bersama guru kelas tentang kegiatan apa yang akan dilakukan. Selanjutnya, peneliti mempersiapkan media pembelajaran untuk permainan modifikasi congklak. peneliti juga menyiapkan lembar observasi kemampuan anak dalam 
mengenal konsep lambang bilangan 1-10, lembar observasi aktivitas guru dan anak dengan menggunakan check list, serta kamera handphone untuk mendokumentasikan proses kegiatan permainan modifikasi congklak.

Pelaksanaan tindakan siklus II, dilakukan selama dua kali pertemuan. Pelaksanaan tindakan siklus II pertemuan pertama dilakukan pada hari Rabu, 29 Januari 2020, pertemuan kedua pada hari Kamis, 30 Januari 2020. Kegiatan penelitian dilakukan sesuai dengan pembelajaran seperti biasanya yaitu terdiri kegiatan pembuka, inti dan penutup. Namun, permainan modifikasi congklak dilakukan pada saat kegiatan inti.

Kegiatan observasi dilakukan bersamaan dengan pelaksanaan tindakan. Hasil yang didapat terkait kemampuan anak dalam mengenal konsep lambang bilangan 1-10, disajikan berikut.

Tabel 45 Rekapitulasi Kemampuan Mengenal Konsep Lambang Bilangan 1-10 Anak Usia 5-6 Tahun di RA/TK ISLAM AMALI pada Siklus II:

\begin{tabular}{|c|c|c|c|c|c|c|c|c|c|}
\hline \multirow{3}{*}{ SIKLUS II } & \multicolumn{9}{|c|}{ Nilai Indikator dalam Angka } \\
\hline & \multicolumn{3}{|c|}{$\begin{array}{c}\text { Membilang/ } \\
\text { Menyebutkan 1- } \\
10\end{array}$} & \multicolumn{3}{|c|}{\begin{tabular}{|c|} 
Mencocokan \\
Pembilang \\
dengan Hasil dari \\
Pembilang
\end{tabular}} & \multicolumn{3}{|c|}{$\begin{array}{c}\text { Mengurutkan } \\
\text { lambang bilangan } \\
1-10\end{array}$} \\
\hline & 1 & 2 & 3 & 1 & 2 & 3 & 1 & 2 & 3 \\
\hline Pertemuan 1 & 2 & 2 & 11 & 2 & 2 & 11 & 2 & 0 & 13 \\
\hline Pertemuan 2 & 1 & 3 & 11 & 1 & 2 & 12 & 1 & 2 & 12 \\
\hline \multicolumn{10}{|c|}{ Nilai indikator dalam Persentase } \\
\hline Pertemuan 1 & $13 \%$ & $13 \%$ & $73 \%$ & $13 \%$ & $13 \%$ & $73 \%$ & $13 \%$ & $0 \%$ & $87 \%$ \\
\hline Pertemuan 2 & $7 \%$ & $20 \%$ & $73 \%$ & $7 \%$ & $13 \%$ & $80 \%$ & $7 \%$ & $13 \%$ & $80 \%$ \\
\hline $\begin{array}{c}\text { Rata-rata } \\
\text { Ketercapaian }\end{array}$ & $10 \%$ & $17 \%$ & $73 \%$ & $10 \%$ & $13 \%$ & $77 \%$ & $10 \%$ & $7 \%$ & 839 \\
\hline
\end{tabular}

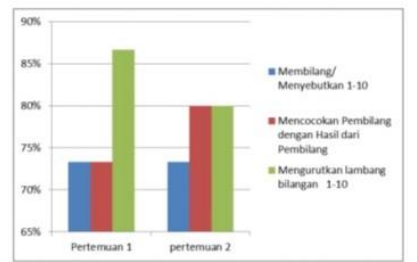

Diagram 43 Diagram Kemapuan Mengenal Konsep Lambang Bilangan 1-10 pada

$$
\text { Siklus II }
$$

Gambar 4. Kemampuan anak dalam mengenal konsep lambing bilangan

Berdasarkan data di atas, menunjukkan bahwa terdapat peningkatan kemampuan anak dalam mengenal konsep lambang bilangan 1-10 pada siklus II. Pada indikator membilang rata-rata ketercapaian anak mendapatkan skor 3 yaitu $73 \%$, pada indikator mencocokan hasil pembilang dengan hasil dari pembilang ratarata ketercapaian anak mendapatkan skor 3 yaitu $77 \%$. Pada indikator mengurutkan lambang bilangan 1-10, rata-rata ketercapaian anak mendapatkan skor 3 yaitu $83 \%$. Nilai peningkatan rata-rata tiap indikator persiklus dari siklus I dan siklus II dapat dijelaskan sebagai berikut:

Tabel 46 Persentase Peningkatan Setiap siklus

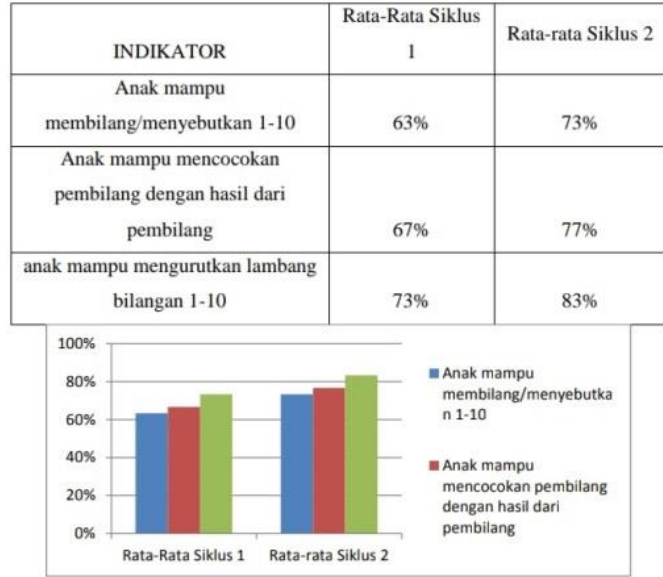

Diagram 44 Diagram Persentase Peningkatan Setiap Siklus

Gambar 5. Peningkatan kemampuan pada setiap siklus

Terkait hasil observasi pada aktivitas guru dan anak, diuraikan melalui tabel berikut ini:
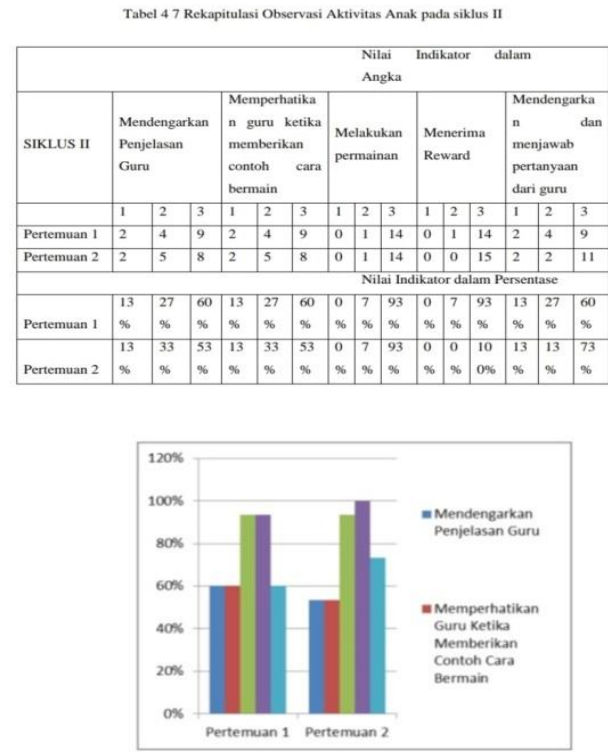

Diagram 45 Diagram Observasi Aktivitas Anak Pada Siklus II

Gambar 6. Hasil observasi aktivitas anak

Berdasarkan data di atas, dapat diketahui bahwa terdapat peningkatan pada masing-masing aktivitas anak di siklus II yaitu anak terlihat mulai lebih tertib dengan mau mendengar, 
memperhatikan dan menjawab pertanyaan dari guru, anak lebih mudah memahami cara permainan modifikasi congklak pada siklus II sehingga sebagian besar anak telah melakukan permainan modifikasi congklak sesuai dengan cara yang telah dicontohkan guru. Selain itu, anak juga sudah mulai memahami tujuan dari pemberian reward.

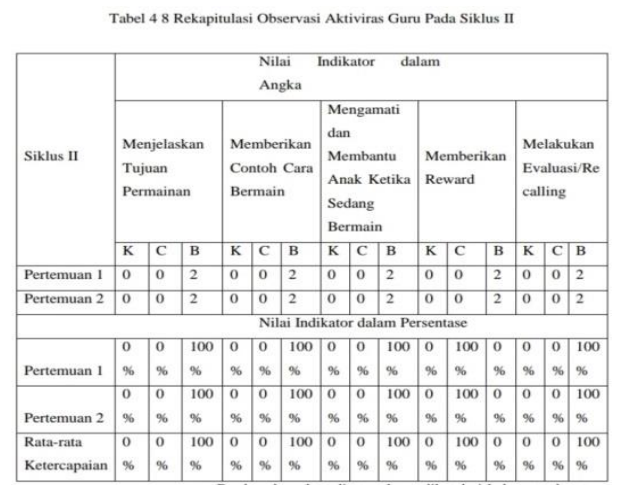

Gambar 7. Hasil rekapitulasi observasi aktivitas guru

Berdasarkan data di atas dapat diketahui bahwa terdapat peningkatan aktivitas guru pada aktivitas menjelaskan tujuan permainan, memberikan contoh cara permainan, mengamati dan membantu anak ketika melakukan permainan modifikasi congklak, memberikan reward serta melakukan evalusi karena sudah mendapatkan skor b (baik) artinya guru dinilai telah melakukan aktivitas tersebut sesuai dengan sebagaimana mestinya.

Berdasarkan hasil observasi, maka refleksi siklus II yaitu didapatkan hasil bahwa terdapat peningkatan pada aktivitas anak dan guru. Di mana pada aktivitas anak, anak terlihat sudah mulai tertib pada saat mendengarkan guru ketika menjelaskan tujuan permainan modifikasi congklak, memperhatikan guru ketika memberikan contoh permainan modifikasi congklak dan mau mendengar serta menjawab pertanyaan dari guru ketika evaluasi. Selain itu, ketika melakukan permainan modifikasi congklak anak terlihat sudah memahami dengan benar cara permainan modifikasi congklak yang telah dicontohkan oleh guru dan dengan adanya reward berupa makanan/jajanan membuat anak merasa senang. Sedangkan, pada aktivitas guru dinilai sudah terdapat peningkatan dari kelima aktivitas yang ada.
Pada siklus II, hambatan-hambatan yang terjadi disiklus I sudah banyak berkurang. Namun, masih terdapat anak yang tidak masuk dan terdapat pula dua anak yang masih membutuhkan bantuan atau bimbingan guru dalam melakukan permainan modifikasi congklak. Tindakan yang peneliti lakukan pada siklus II terlihat lebih baik dibandingkan dengan tindakan siklus I.

Tindakan pada siklus II telah mencapai indikator keberhasilan penelitian, sehingga peneliti menghentikan penelitian ini pada siklus II karena sudah mencapai indikator keberhasilan yang telah ditetapkan yaitu dengan nilai rata-rata ketercapaian dalam membilang $73 \%$, mencocokan $77 \%$ dan mengurutkan $83 \%$. Hasil pada indikator menghubungkan dan mengurutkan belum mencapai $75 \%$, karena dalam pelaksanaannya masih terdapat anak yang tertukar dalam menghubungkan dan terdapat pula anak yang masih harus dibantu atau dibimbing guru dalam mengurutkan lambang bilangan $1-10$. Selain itu terdapat sebagian besar anak yang sudah mampu mendapatkan skor 3, tetapi pada hari dilaksanakannya siklus II mereka tidak masuk ke sekolah, sehingga mempengaruhi nilai presentasi peningkatan kemampuan anak dalam mengenal konsep lambang bilangan $1-10$.

Ketercapaian ini diperoleh karena dalam mengenalkan konsep lambang bilangan $1-10$ dilakukan dengan kegiatan permainan pohon hitung. Melalui permainan pohon hitung dapat mempermudah anak dalam mengenal konsep lambang bilangan baik membilang, menghubungkan dan mengurutkan lambang bilangan $1-10$. Sebagaimana yang telah dijelaskan oleh Tresnawati (dalam Wati, 2015) bahwa media modifikasi congklak merupakan media yang jenisnya visual. Permainan modifikasi congklak adalah mainan edukasi untuk melatih kemampuan anak. Adapun manfaat dari permainan modifikasi congklak yaitu untuk melatih kemampuan kognitif anak seperti berhitung, mengenal angka dan mengenal bentuk angka.

Selain itu, dalam permainan modifikasi congklak dilakukan dengan melibatkan anak secara langsung dalam proses pembelajaran dan menggunakan media pembelajaran lainnya yang membuat kegiatan pembelajaran lebih bermakna karena sebelumnya pada proses 
pembelajaran mengenal konsep lambang bilangan $1-10$ hanya menggunakan lembar aktivitas anak serta papan tulis. Sesuai dengan yang telah dijelaskan PERMENDIKBUD RI Nomor 137 Tahun 2014 bahwa salah satu prinsip pembelajaran anak usia dini adalah belajar melalui bermain, berorientasi pada perkembangan anak, berpusat kepada anak, pembelajaran aktif, dan pemanfaatan media belajar, sumber belajar serta narasumber. Kemudian, faktor lain yang mendukung meningkatnya kemampuan mengenal konsep lambang bilangan 1 - 10 juga dikarenakan adanya reward yang diberikan guru sehingga membuat anak menjadi semangat dan senang dalam mengikuti kegiatan permainan pohon hitung.

Faktor lain yang juga mendukung meningkatnya kemampuan mengenal konsep lambang bilangan 1 - 10 dikarenakan langkahlangkah yang dilakukan dalam permainan pohon hitung sesuai dengan tahapan mengenal lambang bilangan yaitu pertama-tama anak diminta untuk membilang benda-benda konkret, selanjutnya anak memasuki masa peralihan dari konkret ke lambang di mana anak mampu untuk menghubungkan jumlah benda-benda konkret dengan lambang bilangan yang mewakilkan jumlah benda tersebut, setelah itu anak memasuki tahap lambang. Sebagaimana yang telah dijelaskan oleh Burns (dalam Mutiah, 2010: 161 - 162) mengatakan bahwa kelompok matematika yang sudah dapat diperkenalkan mulai dari usia tiga tahun adalah kelompok bilangan (aritmatika, berhitung), pola dan fungsinya, geometri, ukuran-ukuran, grafik estimasi, probabilitas, pemecahan masalah. Penugasan masing-masing kelompok melalui tiga tahapan yaitu tingkat pemahaman, tingkat menghubungkan konsep konkret dengan lambang bilangan dan tingkat lambang bilangan.

\section{SIMPULAN DAN SARAN}

Berdasarkan hasil data yang diperoleh dapat disimpulkan bahwa terdapat peningkatan dalam kemampuan mengenal konsep lambang bilangan 1 - 10 ketika sebelum dan sesudah diterapkannya kegiatan permainan modifikasi congklakpadaanakusia 5 - 6 tahun di RA TK Islam Amali. Nilai peningkatan rata-rata anak yang mendapat skor 3 pada setiap indicator persiklus dari siklus I ke siklus II pada indicator membilang 1-10 siklus I persentase yang mendapatkan skor 3 sebesar $63 \%$ dansiklus II sebesar $73 \%$ artinya terdapat peningkatan sebesar $10 \%$. Indikator mencocokan pembilang dengan hasil dari pembilang, siklus I persentase yang mendapatkan skor 3 sebesar $67 \%$ dan siklus II sebesar $77 \%$ artinyaterdapat peningkatan sebesar $10 \%$. Indikator mengurutkan lambing bilangan 1-10, siklus I persentase yang mendapatkan skor 3 sebesar $73 \%$ dan siklus II sebesar $83 \%$ artinya terdapat peningkatan sebesar $10 \%$.

Terjadinya peningkatan tersebut, dikarenakan dalam mengenalkan konsep lambang bilangan dilakukan dengan melalui permainan modifikasi congklak yang sebelumnya belum pernah diterapkan dalam mengenalkan konsep lambang bilangan kepada anak. Selain itu, dalam merencanakan permainan modifikasi congklak tersebut peneliti beracuan pada teori mengenai tahapan-tahapan mengenal lambang bilangan kepada anak yaitu melalui tingkat pemahaman, tingkat menghubungkan konsep konkret dengan lambang bilangan dan tingkat lambang bilangan. Peningkatan juga terjadi karena adanya motivasi berupa reward yang membuat anak lebih semangat dalam melakukan permainan modifikasi congklak.

Berdasarkan hasil penelitian tersebut, saran yang diberikan kepada guru adalah: 1). Sebaiknya dalam menerapkan permainan modifikasi congklak dilakukan di dalam kelas dengan space yang lebih besar dan memanggil anak secara bergantian agar anak lebih leluasa dalam melakukan permainan; 2). Kartu angka yang disediakan guru dalam kegiatan mengurutkan lambang bilangan sebaiknya tidak telalu banyak, misalnya cukup satu sampai dua set; 3). Sebaiknya dalam mengevaluasi pembelajaran, suara guru dapat lebih lantang agar anak mau mendengarkannya; 4). Reward yang diberikan untuk anak sebaiknya lebih bervariasi sesuai dengan kesukaan anak misalnya makanan seperti wafer; dan, 5). Guru hendaknya memberikan pemahaman kepada orang tua maupun anak agar lebih semangat untuk datang ke sekolah.

Sedangkan bagi kepala sekolah hendaknya mendukung kemampuan mengenal konsep lambang bilangan anak dengan menyediakan media pembelajaran yang bervariasi, misalnya permainan modifikasi congklak. 


\section{DAFTAR PUSTAKA}

Astriyanah. (2015). Meningkatkan kemampuan berhitung anak usia 5-6 tahun melalui kegiatan bermain peran. Jakarta.

Beaty, J. J. (2008). Preschool aprropriate practices. USA: Delmar Cengage Learning.

Charlesworth, R. (2012). Experiences in math for young children. Sixth Edition. USA: Wadsworth.

Desmita. (2009). Psikologi perkembangan. Bandung: PT Remaja Rosdakarya.

Direktorat Permuseuman. (1998). Permainan tradisional indonesia. Indonesia.

Dodge, D.T. (2002). The creative curriculum for preschool. USA; Teaching Strategies.

Ellis, A.K. (2001). Teaching, learning and assesment together: the reflective classroom. New York: Eye On Education.

Expat Web Site Association. Congklak: A Tradisional Games of Indonesia. Diakses dari

http://www.expat.or.id/info/congklak.html pada tanggal 10 Oktiber 2019 pukul 20.30

Fad, A. (2014). Kumpulan permainan anak tradisional indonesia. Jakarta: Cerdas Interaktif.

Feldman, J.R. (1991). A survival guide for the preschool teacher. USA: The Center For Applied Research in Education.

Hurlock, E.. (2004). Psikologi perkembangan. Jakarta: Erlangga.

Kurniati, E (2016). Permainan tradisional dan perannya dalam mengembangkan keterampilan sosial anak. Jakarta: Prenadamedia Group.

Kunandar. (2009). Langkah mudah penelitian tindakan kelas sebagai pengembangan profesi guru. Jakarta: PT. Rajagrafindo Persada.
Berk, L.E. (2006). Children development. USA: Pearson Education.

Fadlillah, M. (2017). Bermain dan permainan. Penerbit Kencana: Jakarta.

Muslich, M. (2009). Melaksanakan PTK itu mudah (classroom action research). Jakarta: PT Bumi Aksara.

Papalia, D.E., et, al. (2008). Human development. psikologi perkembangan. Jakarta: Kencana.

Peraturan Menteri Pendidikan dan Kebudayaan Republik Indonesia No.137 Tahun 2014, Jakarta: Direktorat PAUD.

Sanjaya, W. (2009). Penelitian tindakan kelas. Jakarta: Kencana.

Robbins, S.P., Judge, T.A. (2008). Perilaku organisasi. Jakarta: Salemba Empat.

Tipps, S., et.al. (2011). Guiding children's learning of mathematics. USA: Wadsworth.

Walker, D.G. (2014). A book of historic board games. United States: Lulu Press, Inc.

Wortham, S.C. (2005). Assesment in early childhood education. New Jersey: Pearson Education.

Santrock, J.W. (2007). Perkembangan anak. Penerbit Erlangga: Jakarta.

Sudono, A. (2000). Sumber belajar dan alat permainan untuk pendidikan anak usia dini. Jakarta: Grasindo.

Sukidin, dkk. (2010). Manajemen penelitian tindakan kelas. Banten: Insan Cendikia.

Suroso. (2009). Penelitian tindakan kelas. Yogyakarta: Pararaton.

Smith, S.S. (2009). Early childhood mathematics. USA: Person Education.

Suyadi. (2011). Panduan penelitian tindakan kelas. Yogyakarta: Diva Press.

Syafaruddin. (2012). Pendidikan dan pemberdayaan masyarakat. Medan: Perdana Publishing. 